\title{
Knowledge Construction Models: A view of Various Models for an Impeccable Learning Environment
}

\author{
Suhaizal Hashim, Mimi Mohaffyza Mohamad, Wan Hanim Nadrah Wan Muda \\ Faculty of Technical and Vocational Education, University Tun Hussein Onn Malaysia, Parit Raja, Johor, Malaysia.
}

\begin{abstract}
Knowledge construction plays an important role in determining the effectiveness of learning by focusing on how humans process information and transform it into knowledge. This paper tries to identify the models of knowledge construction process that is suitable for the development of learning environment. The process of constructing student knowledge through a learning system involves an analysis of several types of knowledge construction models used as analytical tools for online learning. The methodology that been used in this paper is thematic analysis. From the analysis, it seems that it is suitable for us to use the Alavi Knowledge Management Process Model to develop a learning environment. Besides, the analysis from Veerman and Veldhuis-Diermanse model also appears to be a better choice as the process in this model able to help construct a social constructivist principle through focusing on non-task related activities to determine the process of knowledge construction. The implementation of online collaborative discussions is said to have great potential to provide opportunities for students to engage intellectually in the process of knowledge construction and in the tradition of cognitive and constructivism learning. Therefore, teachers must be prepared to implement suitable developments and cultures in teaching strategies by providing basic information, involving students to practice and apply relevant skills and implement it in fitting time
\end{abstract}

\section{Introduction}

Knowledge construction is the heart of a learning process that determines the success of any learning effort. In the tradition of cognitive and constructivism learning, knowledge construction plays an important role in determining the effectiveness of learning by focusing on how humans process information and transform it into knowledge [1]. Therefore, regardless of the nature of any learning environment, the issue of knowledge construction is still relevant.

Rahman et al. [2] stated in their study that focusing on the process of knowledge construction in online discussions designed for use with mobile technology found that the majority of the respondents agreed about online discussions helped the process of knowledge construction through critical examinations of other people's ideas during the discussion. The way to cope with psychological barriers is one of an important aspects for online environment that facilitates student engagement to construct knowledge rather than using face-to-face discussions. Further analysis of the learning process reveals the pattern of steps used by the students to build meaning through the discussion process.

A case study report on the discovery of the level of knowledge construction among postgraduate students for six asynchronous computer conferences in blended learning environment Universiti Malaysia Sarawak showed that students were active in knowledge construction but limited to finding and giving opinions about knowledge among friends and explain about the knowledge. Students can benefit from their training in degree programs that incorporate a blended learning environment as a way for them to stay in touch with other students outside the classroom at any time and place [3].

In addition, Zhu [4] also conducted a study on identifying satisfaction, performance and knowledge construction through collaborative online discussion among students in two different cultural contexts. Students from both universities were first year students specializing in educational science from Flemish University and China University. The study found that Flemish students liked to study themselves according to their ability, while Chinese students were very satisfied when they could work with friends to complete their assignment. However, the problem of Flemish students is that working on an online task is very time consuming, while the biggest problem of Chinese students reported is lack of interaction between students and teachers.

Noroozi et al. [5] conducted a study to identify the construction of student knowledge in a computer

*Corresponding author: suhaizal@uthm.edu.my 
learning environment. The combination of computer supported collaborative learning (CSCL) and face to face learning in a new learning environment where students can discuss in front of a shared computer has been used. Their findings show that both students are able to contribute to the better quality of knowledge construction for the second test than the first test.

In a study to evaluate the effectiveness of using video streaming and synchronous forums to provide feedback to presenters in oral skills tutorials by Thanasingam and Soong [6] which emphasizes the quality of knowledge in the form of feedback constructed by students. The findings show that discussion forums encourage understanding and erudition among students as they jointly process their comment through various phases of knowledge construction. This allows them to improve the quality and accuracy of their comment. Thus, this paper tries to identify the models of knowledge construction process that is suitable for the development of learning environment. The existence of an online learning environment based on internet technology enables the knowledge construction process for collaborative discussions held.

\section{Different Models of Knowledge Construction Process}

In order to identify the models of knowledge construction process that is suitable for the development of learning environment, a review process has been carried out as in Table 1 which shows the analysis of 3 models of knowledge construction process. These three models were analyzed by Paavola, Lipponen, and Hakkarainen [7] according to the type of model. Each of these models has the advantages and disadvantages in helping the process of students' knowledge construction.

Table I: Analysis Of The 3 Models Of Knowledge Construction Process By Paavola, Lipponen And Hakkarainen

\begin{tabular}{|l|l|l|l|}
\hline \multirow{2}{*}{ Content } & \multicolumn{3}{|c|}{ Model Types } \\
\cline { 2 - 4 } & $\begin{array}{l}\text { Nonaka and } \\
\text { Takeuchi }\end{array}$ & Engeström & Bereiter \\
\hline $\begin{array}{l}\text { The role } \\
\text { of } \\
\text { individual } \\
\text { expertise }\end{array}$ & $\begin{array}{l}\text { Black box } \\
\text { method where } \\
\text { individuals } \\
\text { create } \\
\text { knowledge }\end{array}$ & $\begin{array}{l}\text { Social } \\
\text { application }\end{array}$ & $\begin{array}{l}\text { Expertise } \\
\text { theory }\end{array}$ \\
\hline $\begin{array}{l}\text { The main } \\
\text { focus }\end{array}$ & $\begin{array}{l}\text { Implicit } \\
\text { Knowledge } \\
\text { (Overview) }\end{array}$ & $\begin{array}{l}\text { Knowledge } \\
\text { found in } \\
\text { practice } \\
\text { (Acts) }\end{array}$ & $\begin{array}{l}\text { Knowledge } \\
\text { object } \\
\text { (Concept) }\end{array}$ \\
\hline $\begin{array}{l}\text { The type } \\
\text { of process } \\
\text { that is } \\
\text { focused }\end{array}$ & $\begin{array}{l}\text { Emphasize the } \\
\text { process } \\
\text { through } \\
\text { personal deeds }\end{array}$ & $\begin{array}{l}\text { Emphasize } \\
\text { object- } \\
\text { oriented } \\
\text { material }\end{array}$ & $\begin{array}{l}\text { Emphasize } \\
\text { solving } \\
\text { knowledge } \\
\text { problems }\end{array}$ \\
\hline
\end{tabular}

\begin{tabular}{|l|l|l|l|}
\hline & $\begin{array}{l}\text { and } \\
\text { experiences }\end{array}$ & activity & \\
\hline $\begin{array}{l}\text { The } \\
\text { source of } \\
\text { innovation }\end{array}$ & $\begin{array}{l}\text { The } \\
\text { transformation } \\
\text { of knowledge } \\
\text { is implied with } \\
\text { clear } \\
\text { knowledge }\end{array}$ & $\begin{array}{l}\text { Overcoming } \\
\text { tension, } \\
\text { chaos, and } \\
\text { ambiguity } \\
\text { through } \\
\text { progressive } \\
\text { learning }\end{array}$ & $\begin{array}{l}\text { Work } \\
\text { deliberately } \\
\text { to expand } \\
\text { and create } \\
\text { new } \\
\text { knowledge } \\
\text { objects }\end{array}$ \\
\hline $\begin{array}{l}\text { Scope of } \\
\text { framewor } \\
\mathrm{k}\end{array}$ & $\begin{array}{l}\text { Different levels } \\
\text { of ontology } \\
\text { (innovative } \\
\text { teams, } \\
\text { organizations } \\
\text { and between } \\
\text { individual level } \\
\text { organizations }\end{array}$ & $\begin{array}{l}\text { Activity } \\
\text { system and } \\
\text { network } \\
\text { activity } \\
\text { system }\end{array}$ & $\begin{array}{l}\text { Knowledge } \\
\text { construction } \\
\text { community }\end{array}$ \\
\hline $\begin{array}{l}\text { Applicatio } \\
\text { ns in } \\
\text { education }\end{array}$ & $\begin{array}{l}\text { School to } \\
\text { create } \\
\text { Knowledge }\end{array}$ & $\begin{array}{l}\text { School as a } \\
\text { learning } \\
\text { progress }\end{array}$ & $\begin{array}{l}\text { School as } \\
\text { knowledge } \\
\text { construction } \\
\text { society }\end{array}$ \\
\hline
\end{tabular}

One of the theories found in the process of knowledge construction is Knowledge-Construction Community. In this learning situation, students will develop knowledge-oriented issues that are more complex and at the same time the students will improve their learning progress. This approach developed by Carl Bereiter [8] who considers that in the process of learning, the approach is to put students as teachers, where in the learning situation, students will do something similar with teacher behaviour, even though they do not have the same knowledge or experience owned by the teachers.

Bereiter [8] has criticized the tendency of some mentalistic over-theory of learning and views the learning process as the amount of information in a person's mind and that thought is regarded as a record of knowledge. The process of knowledge construction that involves work in a particular competence can improve one's achievement as well as to achieve knowledge progress, not only on individual learning but also on group learning. The type of learning by Bereiter [8] is designed activities to create mutual knowledge, which requires the collaboration to create, develop, understand and criticize. Its main purpose is not only learning something but also to collaborate in developing new methods, theories, models and so forth that can be used in the future.

The basic point raised in the construction of this community knowledge is more towards the method of presentation that is learning with this method of presentation. It can be seen as one of the best methods to determine the ability to build knowledge for students and if it developed in schools, it can help them to build knowledge and train them to communicate and display themself. If we view it further and linked to the theories 
by Nonaka and Takeuchi [9], the main points raised in the theory of knowledge construction of this community are more on the method of delivery. According to Engeström [10], the main problem with Nonaka and Takeuchi model [9] is that it does not take into account the first two phases of the expansive model, which are questioning and analyzing the situation. Their model is based on too many ideas to share the implicit knowledge in the phase of socialization and does not take into account the importance of controversy and conflict in the creation of knowledge.

There are some drawbacks from the analysis of all these models and it seems that it is suitable to use the Alavi Knowledge Management Process Model [11] to established a suitable learning environment. The model in knowledge management involves the rotation of the activity for example knowledge needs to be developed, stored, channeled and need to be combined as well as refer to a systematic and manageable specific process for obtaining, handling and delivering both the tasit and explicit knowledge acquired from a student so they can use it to improve the efficiency and productivity of their assignments [12][13]. Alavi and Leidner [13] also suggest that knowledge management involves four key processes, namely knowledge creation, knowledge storage, knowledge transfer and knowledge application.

Knowledge Creation is the process of claiming that knowledge will be created when two different people share their knowledge and explicit knowledge with one another. The process of creating knowledge and content development can be achieve by organizing experiences and learning from lessons learned by collecting, synthesizing and interpreting information. Then, knowledge storage is a process whereby the knowledge received will be processed and stored. The following three phases that include in knowledge storage are indexing, filtering and linking references to resource management activities that include checking, classifying, cataloging, integrating and linking content from both knowledge sources both internal and external.

Furthermore, knowledge transfer is a process once the knowledge is acquired and stored in order to enable it to be used, this knowledge should be disseminated or transferred to the party requiring it to be used. Finally, knowledge application is a phase that determines of whether an organization can apply the knowledge they have to become more competitive. This phase uses knowledge that has been collected, stored and transmitted or otherwise, it is a level of knowledge received in the form of tacit and explicit that will be used in the same situation by other individuals. Figure 1 shows the Alavi Knowledge Management Process Model [11] which states that knowledge management refers to a systematic and manageable specific process for obtaining, handling and delivering both the tacit and explicit knowledge acquired from a student so that other students can also use it to increase the level of efficiency and productivity of their projects.

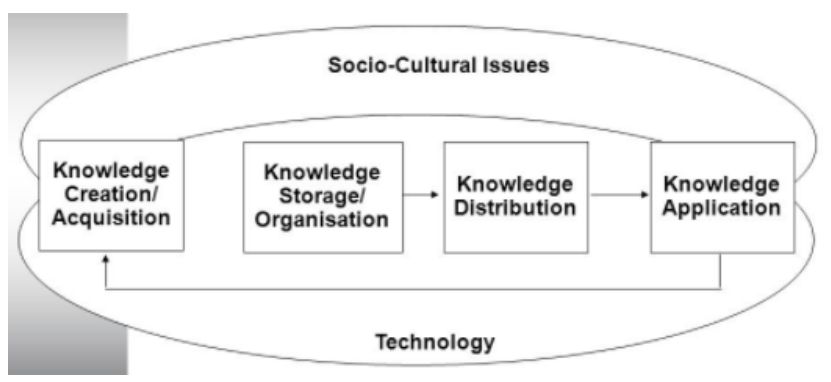

Figure 1: Alavi Knowledge Management Process Model

After a thematic analysis had been done, there are several factors that encourage the selection of this model amongst others as the involvement of Alavi itself who involved in several studies on the process of collaborative assessment and learning. One of the studies itself is to test the effectiveness of the use of the Group Decision Support System in the collaborative learning process to enhance Student learning experience and classroom assessment. According to Alavi, Yoo and Vogel [14], an innovation in management education is to use information technology to create value-added partnerships between universities to leverage student learning experiences through a diverse range of resources and technologies where students have the opportunity to interact with their friends and teachers simultaneously via video conference facilities. This study also shows how this information technology can enable collaborative learning and teaching to take place in different groups of students, diversity of teachers and integration of outside expertise.

Alavi and Dufner [15] stated that the technology from internet network open more space for collaboration and through their research also showed that compared to individualized learning, collaborative learning shows better psychological relationship and academic achievement, add self-confidence and it improve psychological level of a person. In order to increase the knowledge of teachers and students, the Internet technology is seen as one of the channels for the process of knowledge construction. The implementation of online collaborative discussions is said to have great potential to provide opportunities for students to engage intellectually in the process of knowledge construction and in the tradition of cognitive and constructivism learning. Knowledge construction plays an important role in determining the effectiveness of the learning process [16]. 


\section{Analysis Of Knowledge Construction Process Based On Support Type}

The analysis of the process of constructing student knowledge through a learning system involves an analysis of several types of knowledge construction models used as analytical tools for online learning. Online learning refers to a learning environment that uses internet technology to enable virtual learning sessions to take place. There are three interrelated elements used by Oliver [17] in describing web-based teaching designs which are learning resources, learning support and learning assignments. Table 2 is the analysis of the process of knowledge construction based on the type of support is the hypothesis that students use different knowledge construction models in the online learning environment compared to learning in a traditional setting.

Table II: Analysis Of Knowledge Construction Based On Support Type

\begin{tabular}{|c|c|c|c|}
\hline $\begin{array}{c}\text { Researc } \\
\text { her }\end{array}$ & $\begin{array}{l}\text { Research } \\
\text { Objectives }\end{array}$ & $\begin{array}{l}\text { Support } \\
\text { Type }\end{array}$ & $\begin{array}{c}\text { Knowledge } \\
\text { Construction } \\
\text { Analysis }\end{array}$ \\
\hline $\begin{array}{l}\text { Kanuka, } \\
\text { H. and } \\
\text { Anderso } \\
n, T \text {. } \\
{[18] .}\end{array}$ & $\begin{array}{l}\text { This study } \\
\text { presents the } \\
\text { results of } \\
\text { exploratory } \\
\text { studies of } \\
\text { various } \\
\text { evaluation and } \\
\text { analysis } \\
\text { methods for } \\
\text { online forum } \\
\text { transcripts. }\end{array}$ & $\begin{array}{l}\text { Online } \\
\text { forums. }\end{array}$ & $\begin{array}{l}\text { An analysis of } \\
\text { five phase } \\
\text { content model } \\
\text { that explains } \\
\text { the steps in } \\
\text { knowledge } \\
\text { construction } \\
\text { (Gunawarden } \\
\text { a, Lowe and } \\
\text { Anderson). }\end{array}$ \\
\hline $\begin{array}{l}\text { Schellen } \\
\text { s, T. dan } \\
\text { Valcke, } \\
\text { M. [19]. }\end{array}$ & $\begin{array}{l}\text { This study to } \\
\text { identify } \\
\text { collaborative } \\
\text { learning in an } \\
\text { asynchronous } \\
\text { discussion } \\
\text { group resulting } \\
\text { in an increase } \\
\text { in academic } \\
\text { performance } \\
\text { and knowledge } \\
\text { construction. }\end{array}$ & $\begin{array}{l}\text { Face-to-face } \\
\text { lectures with } \\
\text { options for } \\
\text { participation } \\
\text { in online } \\
\text { discussion } \\
\text { groups. } \\
\text { Group } \\
\text { discussions } \\
\text { focus on the } \\
\text { same } \\
\text { learning } \\
\text { objectives as } \\
\text { a face-to- } \\
\text { face lecture } \\
\text { session. }\end{array}$ & $\begin{array}{l}\text { Each } \\
\text { complete } \\
\text { message } \\
\text { analyses using } \\
\text { coding } \\
\text { process from } \\
\text { the Veerman } \\
\text { and Veldhuis- } \\
\text { Diermanse } \\
\text { models. }\end{array}$ \\
\hline
\end{tabular}

\begin{tabular}{|c|c|c|c|}
\hline $\begin{array}{l}\text { Ortegano } \\
\text {-Layne, } \\
\text { Gunawar } \\
\text { dena } \\
{[20] .}\end{array}$ & $\begin{array}{l}\text { This study to } \\
\text { determine } \\
\text { whether a } \\
\text { concept map } \\
\text { can be used to } \\
\text { synthesize the } \\
\text { construction of } \\
\text { knowledge in } \\
\text { online } \\
\text { discussions and } \\
\text { to determine } \\
\text { whether a } \\
\text { moderator } \\
\text { carrying an } \\
\text { online } \\
\text { discussion can } \\
\text { use a concept } \\
\text { map as a tool } \\
\text { that capable of } \\
\text { assisting them. }\end{array}$ & $\begin{array}{l}\text { Online } \\
\text { courses } \\
\text { designed } \\
\text { using } \\
\text { WebCT } \\
\text { learning } \\
\text { management } \\
\text { systems. }\end{array}$ & $\begin{array}{l}\text { An analysis of } \\
\text { five phase } \\
\text { content model } \\
\text { that explains } \\
\text { the steps in } \\
\text { knowledge } \\
\text { construction } \\
\text { (Gunawarden } \\
\text { a, Lowe and } \\
\text { Anderson). }\end{array}$ \\
\hline $\begin{array}{l}\text { Kumar, } \\
\text { S. [21]. }\end{array}$ & $\begin{array}{l}\text { This study aims } \\
\text { to determine } \\
\text { whether face- } \\
\text { to-face course } \\
\text { discussions } \\
\text { using } \\
\text { asynchronous } \\
\text { communication } \\
\text { tools facilitate } \\
\text { the } \\
\text { construction of } \\
\text { knowledge in } \\
\text { the same way } \\
\text { as online } \\
\text { discussions in } \\
\text { online courses. }\end{array}$ & $\begin{array}{l}\text { Web-based } \\
\text { course } \\
\text { management } \\
\text { system, } \\
\text { CourseInfo. }\end{array}$ & $\begin{array}{l}\text { An analysis of } \\
\text { five phase } \\
\text { content model } \\
\text { that explains } \\
\text { the steps in } \\
\text { knowledge } \\
\text { construction } \\
\text { (Gunawarden } \\
\text { a, Lowe and } \\
\text { Anderson). }\end{array}$ \\
\hline $\begin{array}{l}\text { Thanasin } \\
\text { gam, S. } \\
\text { and } \\
\text { Soong, } \\
\text { S. K. A. } \\
{[6] \text {. }}\end{array}$ & $\begin{array}{l}\text { This study } \\
\text { assesses the } \\
\text { effectiveness of } \\
\text { video } \\
\text { streaming and } \\
\text { discussion of } \\
\text { synchronous } \\
\text { forums to } \\
\text { provide } \\
\text { feedback to } \\
\text { speakers in oral } \\
\text { skills tutorials }\end{array}$ & $\begin{array}{l}\text { Online } \\
\text { tutorial } \\
\text { prototype }\end{array}$ & $\begin{array}{l}\text { Knowledge } \\
\text { construction } \\
\text { phase of } \\
\text { Gunawardena } \\
\text { et.al. }\end{array}$ \\
\hline $\begin{array}{l}\text { García, } \\
\text { B., } \\
\text { Márquez } \\
\text {, L., } \\
\text { Bustos, } \\
\text { A., } \\
\text { Miranda, } \\
\text { G. A., \& } \\
\text { Espíndol } \\
\text { a S. M. } \\
\text { [23]. }\end{array}$ & $\begin{array}{l}\text { This study } \\
\text { provides } \\
\text { suggestions } \\
\text { that consider } \\
\text { the contextual } \\
\text { factors that } \\
\text { make up the } \\
\text { input and } \\
\text { interaction } \\
\text { scenarios, the } \\
\text { interaction } \\
\text { process: type of } \\
\text { interaction and } \\
\text { its contents and } \\
\text { the learning }\end{array}$ & $\begin{array}{l}\text { Computer- } \\
\text { mediated } \\
\text { communicat } \\
\text { ion }(\mathrm{CMC}) \text {. }\end{array}$ & $\begin{array}{l}\text { An analysis of } \\
\text { five phase } \\
\text { content model } \\
\text { that explains } \\
\text { the steps in } \\
\text { knowledge } \\
\text { construction } \\
\text { (Gunawarden } \\
\text { a, Lowe and } \\
\text { Anderson). }\end{array}$ \\
\hline
\end{tabular}




\begin{tabular}{|c|c|c|c|}
\hline & $\begin{array}{l}\text { strategies and } \\
\text { decisions that } \\
\text { involve the } \\
\text { quality of } \\
\text { knowledge } \\
\text { constructed by } \\
\text { participants. }\end{array}$ & & \\
\hline $\begin{array}{l}\text { Kian- } \\
\text { Sam, H., } \\
\text { and Lee, } \\
\text { J. A. C. } \\
\text { [3]. }\end{array}$ & $\begin{array}{l}\text { This study to } \\
\text { identify the } \\
\text { level of } \\
\text { knowledge } \\
\text { construction } \\
\text { among } \\
\text { postgraduate } \\
\text { students in six } \\
\text { asynchronous } \\
\text { computer } \\
\text { sessions in a } \\
\text { blended } \\
\text { learning } \\
\text { environment }\end{array}$ & $\begin{array}{l}\text { Quickplace, } \\
\text { an elearning } \\
\text { system at } \\
\text { Universiti } \\
\text { Malaysia } \\
\text { Sarawak. }\end{array}$ & $\begin{array}{l}\text { Each } \\
\text { complete } \\
\text { message } \\
\text { analyses using } \\
\text { coding } \\
\text { process from } \\
\text { the Veerman } \\
\text { and Veldhuis- } \\
\text { Diermanse } \\
\text { models. }\end{array}$ \\
\hline $\begin{array}{l}\text { Rahman, } \\
\text { S., } \\
\text { Yasin, } \\
\text { R. M., } \\
\text { Jusoff, } \\
\text { K., } \\
\text { Yassin, } \\
\text { S. F. M., } \\
\text { Nordin, } \\
\text { N. M., \& } \\
\text { Yusof, } \\
\text { M. M. } \\
\text { [6]. }\end{array}$ & $\begin{array}{l}\text { The process of } \\
\text { knowledge } \\
\text { construction in } \\
\text { online } \\
\text { discussions } \\
\text { designed for } \\
\text { the use with } \\
\text { mobile } \\
\text { technology. }\end{array}$ & $\begin{array}{l}\text { Students } \\
\text { were asked } \\
\text { to } \\
\text { participate } \\
\text { in online } \\
\text { discussions } \\
\text { about what } \\
\text { they } \\
\text { understand } \\
\text { on the } \\
\text { subject they } \\
\text { have } \\
\text { learned. }\end{array}$ & Not mention \\
\hline $\begin{array}{l}\text { Zhu, C. } \\
{[4] .}\end{array}$ & $\begin{array}{l}\text { This study to } \\
\text { examine the } \\
\text { satisfaction, } \\
\text { performance } \\
\text { and build of } \\
\text { knowledge } \\
\text { through student } \\
\text { online } \\
\text { discussions } \\
\text { group with two } \\
\text { different } \\
\text { cultural } \\
\text { contexts. }\end{array}$ & $\begin{array}{l}\text { Elearning } \\
\text { using open } \\
\text { source } \\
\text { platforms } \\
\text { based on } \\
\text { Dokeos }\end{array}$ & $\begin{array}{l}\text { The coding } \\
\text { schemes of } \\
\text { Veerman and } \\
\text { Veldhuis- } \\
\text { Diermanse) } \\
\text { were used to } \\
\text { analyze the } \\
\text { distribution of } \\
\text { communicatio } \\
\mathrm{n} \text { types and } \\
\text { coding } \\
\text { schemes of } \\
\text { Gunawardena, } \\
\text { Lowe, and } \\
\text { Anderson to } \\
\text { analyze the } \\
\text { social level of } \\
\text { knowledge } \\
\text { construction. }\end{array}$ \\
\hline
\end{tabular}

\begin{tabular}{|c|c|c|c|}
\hline $\begin{array}{l}\text { Noroozi, } \\
\text { O., } \\
\text { Biemans } \\
\text {, H., } \\
\text { Mulder, } \\
\text { M. dan } \\
\text { Chizari, } \\
\text { M. [5]. }\end{array}$ & $\begin{array}{l}\text { Identify of } \\
\text { student } \\
\text { knowledge } \\
\text { construction in } \\
\text { a computer } \\
\text { supported } \\
\text { learning } \\
\text { environment in } \\
\text { the nutrition } \\
\text { research on } \\
\text { domain } \\
\text { nutritionology } \\
\text { methodology. }\end{array}$ & $\begin{array}{l}\text { Combinatio } \\
\mathrm{n} \text { of } \\
\text { Computer } \\
\text { Supported } \\
\text { Collaborativ } \\
\text { e Learning } \\
\text { (CSCL) and } \\
\text { face to face } \\
\text { learning in a } \\
\text { learning } \\
\text { environment } \\
\text { where } \\
\text { students can } \\
\text { discuss in } \\
\text { front of } \\
\text { shared } \\
\text { computers. }\end{array}$ & $\begin{array}{l}\text { Veldhuis- } \\
\text { Diermanse } \\
\text { encoding } \\
\text { scheme was } \\
\text { used to } \\
\text { analyze the } \\
\text { construction } \\
\text { of student } \\
\text { knowledge. }\end{array}$ \\
\hline $\begin{array}{l}\text { Hashim, } \\
\text { S., \& } \\
\text { Harun, J. } \\
{[23]}\end{array}$ & $\begin{array}{l}\text { Examine the } \\
\text { impact of CPA } \\
\text { learning system } \\
\text { as a medium } \\
\text { for the process } \\
\text { of knowledge } \\
\text { construction in } \\
\text { helping the } \\
\text { learning and } \\
\text { teaching } \\
\text { process. }\end{array}$ & $\begin{array}{l}\text { CPA } \\
\text { learning } \\
\text { system }\end{array}$ & $\begin{array}{l}\text { Veldhuis- } \\
\text { Diermanse } \\
\text { encoding } \\
\text { scheme was } \\
\text { used to } \\
\text { analyze the } \\
\text { construction } \\
\text { of student } \\
\text { knowledge. }\end{array}$ \\
\hline
\end{tabular}

From the analysis, It seems that the analysis model of Veerman and Veldhuis-Diermanse [24] appears to be a better choice as the process in this model was able to construct a social constructivist principle through focusing on non-task related activities to determine the process of knowledge construction. The model of Veerman and Veldhuis-Diermanse distinguishes between task-oriented and non-task-oriented messages based on encoded behavioral features. These differences help to control interpersonal monitoring activities in the process of students' knowledge construction. This topology is more common than the Gunawardena et al. [25] as it is more specific by suggesting alternatives to assessing the construction of knowledge through social negotiations concluded with interaction analysis model that encompasses five phases and reflects the process of negotiations that occur in a social constructivist learning environment. Gunawardena et al. was found to be more suitable to determine the level of knowledge construction process.

The analysis model of Veerman and VeldhuisDiermanse has also been used as a content analysis for several studies in online collaborative learning environments, among them Schellens and Valcke [19] who have conducted studies to identify collaborative learning in an asynchronous discussion group resulting in increased academic performance and knowledge construction. The results of the study confirmed that discussions of the students in the group were highly taskoriented and the ratio of high knowledge construction 
phase was also observed. There were also significant improvements in cognitive interaction, task, orientation and higher knowledge construction phase detected.

Walker [26] supports this statement by expressing written assignments such as answering and responding to other student discussion questions can increase knowledge construction. Besides, analyzing case studies, report writing, project summaries, research papers and collaborative written assignments such as preparing team reports on specific topics, group discussion questions, debates and criticisms also help students to increase knowledge construction. Parker [27] in his research demonstrates that in order to influence the students' knowledge, skills and behavior, teachers must be prepared to implement suitable developments and cultures in teaching strategies by providing basic information, involving students to practice and apply relevant skills and implement it in fitting time.

\section{Conclusion}

The development of multimedia technology demonstrates the great potential of transforming student's method of learning, how to obtain information and how to adapt information. Teachers' explanations about things can be easy to understand when assisted by a variety of materials and tools that capable to interpret a clear meaning about the matters. The use of attractive and concrete visual materials not only enhances students' understanding of the topic, it also has an insightful effect on the student's personality.

In building their own understanding, students may accept this new idea and throw away their old ideas because they feel that the idea does not fit their judgment. In every situation, they are actually building understanding on new ideas and constructing knowledge based on the experiences they have had or their existing ideas. Students who come to the classroom are individuals who carry out a variety of experiences and knowledge that will be the basis of new knowledge to be built.

This new knowledge is built on itself as this student aligns with the past experiences and the existing ideas they bring to the classroom. Opinion in constructivism will put students into centers in the teaching and learning process. Collaborative activity through discussion seems to be an important aspect of teaching and learning in constructivism. The discussion method is widely used for knowledge construction process as this method can provide a collaborative learning environment and facilitate students to participate in online communication.

The authors would like to thank the Universiti Tun Hussein Onn Malaysia (UTHM) for their support in making this project possible. Part of this work was supported by the Research University Grant initiated by UTHM under PPG VOT V003.

\section{References}

[1] Woolfolk, A. (2008). Educational Psychology.(10 $0^{\text {th }}$ ed.) New Jersey: Allyn and Bacon.

[2] Rahman, S., Yasin, R. M., Jusoff, K., Yassin, S. F. M., Nordin, N. M., \& Yusof, M. M. (2011). Knowledge construction process in online learning. Middle East Journal of Scientific Research, 8(2), 488-492. Kian-Sam, H., dan Lee, J. A. C. (2008). Postgraduate students' during asynchronous computer conferences in a blended learning environment: A Malaysian experience. Australasian Journal of Educational Technology, 24(1), 91-107.

[3] Kian-Sam, H. \& Lee, J. A. C. (2008). Postgraduate students' during asynchronous computer conferences in a blended learning environment: A Malaysian experience. Australasian Journal of Educational Technology, 24(1), 91-107.

[4] Zhu, C. (2012). Student Satisfaction, Performance, and Knowledge Construction in Online Collaborative Learning. Educational Technology \& Society, 15 (1), 127-136.

[5] Noroozi, O., Biemans, H., Mulder, M. \& Chizari, M. (2010). Students' Knowledge Construction in Computer-Supported Learning Environments: A Comparative Study in the Domain of Nutritional Research Methodology Education. In Society for Information Technology \& Teacher Education International Conference. March 2010. Vol. 2010, No. 1, pp. 2506-2513.

[6] Thanasingam, S. \& Soong, S. K. A. (2007). Interaction patterns and knowledge construction using synchronous discussion forums and video to develop oral skills. In ICT: Providing choices for learners and learning. Proceedings ascilite Singapore 2007.

[7] Paavola S., Lipponen, L. \& Hakkarainen K. (2002). Epistemological Foundations for CSCL: A comparison of three modes of innovative knowledge communities. In G. Stahl, (Ed), 4th CSCL: Foundations for a CSCL Community, (CSCL-2002), Boulder, Colorado, January 2002, pp.24-32, LEA, NJ. USA.

[8] Bereiter, C. (2002). Education and mind in the knowledge age. Mahwah, NJ: Lawrence Erlbaum Associates.

[9] Nonaka, I. \& Takeuchi, H. (1995). The Knowledge-Creating Company: How Japanese Companies Create the Dynamics of Innovation, Oxford University Press, New York.

[10] Engeström, Y. (2000). Activity theory and the social construction of knowledge: A story of four umpires. Organization, 7(2), 301-310.

[11] Alavi, M. (1997). KPMG Peat Marwick U.S.: One Giant Brain, Case 9-397- 108 Boston, MA: Harvard Business School.

[12] Alavi, M. \& Leidner, D. E. (1999). Knowledge management systems: issues, challenges, and benefits. Communications of the AIS, 1(2es).

[13] Alavi, M. \& Leidner, D. E. (2001). Review: Knowledge management and knowledge management systems: Conceptual foundations and research issues. MIS quarterly, 107-136.

[14] Alavi, M., Yoo, Y. \& Vogel, E. R. (1997). Using information technology to add value to management education.Academy of Management Journal, 40(6), 1310-1333.

[15] Alavi, M. \& Dufner, D. (2005). Technology-mediated collaborative learning: a research perspective. In S.R. Hiltz and R. Goldman (Eds.).Learning Together Online: Research on Asynchronous Learning Networks,. (pp. 191-213). Mahwah, NJ: Lawrence Erlbaum Associates.

[16] Rahman, S., Yasin, R. M., Jusoff, K., Yassin, S. F. M., Nordin, N. M., \& Yusof, M. M. (2011). Knowledge Construction Process in Online Learning, Middle-East Journal of Scientific Research 8 (2): 488-492, 2011.

[17] Oliver, R. (2001). Developing e-learning environments that support knowledge construction in higher 10.education. In: S. Stoney and J. Burn, (Eds). Working for excellence in the economy. Churchlands: Australia, pp: 407-416. 
[18] Kanuka, H. \& Anderson, T. (2007). Online social interchange, discord, and knowledge construction. The Journal of Distance Education / Revue de l'Éducation à Distance, 13(1), 57-74.

[19] Schellens, T. \& Valcke, M. (2006). Fostering knowledge construction in university students through asynchronous discussion groups. Computers \& Education, 46(4), 349-370.

[20] Cañas, A. J., Novak, J. D., González, F. M., Ortegano-layne, L. \& Gunawardena, C. N. (2008). Synthesizing social construction of knowledge in online conferences using concept maps.

[21] Kumar, S. (2005). Student Knowledge Construction during Asynchronous Online Discussions in a Face-to-Face Course, World Conference on Educational Multimedia, Hypermedia and Telecommunications. Vol. 2005.No. 1. 2005.

[22] García, B., Márquez, L., Bustos, A., Miranda, G. A. \& Espíndola, S. M. (2008). Analysis of Patterns of Interaction and Knowledge Construction in Online Learning Environments: A Methodological Strategy. Revista Electrónica de Investigación Educativa, 10(1), 2.

[23] Hashim, S. \& Harun, J. (2014, April). Effects of CSCL Learning Approach for Students' Knowledge Construction Process in School Based Assessment (SBA) Environment. In Teaching and
Learning in Computing and Engineering (LaTiCE), 2014 International Conference on (pp. 293-298). IEEE.

[24] Veerman, A. \& Veldhuis-Diermanse, E. (2001). Collaborative learning through computer-mediated communication in academic education.

[25] Gunawardena, C. N., Lowe, C. A. \& Anderson, T. (1997). Analysis of a global online debate and the development of an interaction analysis model for examining social construction of knowledge in computer conferencing. Journal of educational computing research, 17(4), 397-431.

[26] Walker, G. (2005). Critical thinking in asynchronous discussions.International Journal of Instructional Technology and Distance Learning, 6(2).

[27] Parker, J. K. (2010). Understanding youth and digital media. In. J.K. Parker (Ed.) Teaching Tech-Savvy Kids: Bringing Digital Media Into the Classroom, Grades 5-12. Thousand Oaks, California:

Corwin. 